\title{
Effect of IGF-1 on Expression of GH Receptor, IGF-1, IGF-1 Receptor, KAP3.2 and KAP6-1 mRNA in the Skin of Sheep
}

\author{
Chengxian Zhang \\ College of Animal science, Shihezi University \\ Xinjiang 832000, China \\ E-mail: zhangchengxian@126.com \\ Herong Liao (Corresponding author) \\ College of animal breeding and genetics, Shihezi University \\ Xinjiang 832000, China \\ Tel: 86-993-206-6527Ｅ-mail: liaoherong@tom.com \\ Yan Zhao \\ College of Animal science, Shihezi University \\ Xinjiang 832000, China \\ Tel: 86-535-726-2978Ｅ-mail: zhaoyanzy@yahoo.cn
}

\begin{abstract}
Thirty-six healthy and similar Chinese Merino sheep were selected and divided into six groups at random. The treatment group was injected intradermally with $0.5 \mathrm{~mL}$ IGF-1 $(10 \mathrm{ng} / \mathrm{mL})$. Treatment skin tissue of sheep were sampled respectively for $0,3,6,9,12$ and 50 days and the skin expression of growth hormone receptor (GHR), insulin-like growth factor1 (IGF-1), insulin-like growth factor receptor (IGF- R), KAP3.2 and KAP6-1 mRNA were measured by RT-PCR. The results indicated that IGF-1 could degrade GHR gene expression, have no effect of IGF-1 and IGF-1R gene expression, and increase significantly KAP3.2 and KAP6-1 gene expression. Taken together these findings that the improvement of KAP3.2 and KAP6-1 gene expression may correlates with other pathway beyond the insulin-like growth factor axis.
\end{abstract}

Keywords: Sheep, Gene expression, Growth hormone receptor (GHR), Insulin-like growth factor1 (IGF-1), Insulin-like growth factor receptor (IGF-1R), Keratin intermediate filament-associated protein 3.2 (KAP3.2), Keratin-associated protein 6-1(KAP6-1)

\section{Introduction}

Insulin-like growth factor I (IGF-1) and insulin-like growth factor II (IGF-II), as main insulin-like growth factor family, have an irritant effect on hair follicle epithelium and dermis, especially IGF-1 more significant than IGF-II. Extrinsic IGF-1 not only stimulate the DNA synthesis and keratinocyte proliferation of human skin in vitro culture, but also stimulate hair follicle growth in vitro culture, and impact hair follicle morphological development. In contrast, IGF-1 was injected either in vein or subcutaneous sectional in vivo; there were no significant changes in wool growth. But it is indispensable that IGF-1 maintains the wool normal growth, particularly early stage of hair follicle cycling, and prevents hair follicle from accessing catagen in advance. So the modulation of IGF-1 to hair follicle remains ambiguous at present.

We focus on the abundance of GHR, IGF-1, IGF-1R, KAP3.2 and KAP6-1 mRNA in sheep skin by injecting IGF-1 into local subcutaneous tissue periodically and quantitatively, and on the influence of IGF-1 to the expression of the previous gene related to hair follicle growth, which would lay a foundation for further study the modulation of growth factors to hair follicle. 


\section{Materials and Methods}

\subsection{Experimental design}

Thirty-six healthy and similar Chinese Merino sheep were selected and divided into six groups at random. The treatment group was injected intradermally with $0.5 \mathrm{~mL}$ IGF-1 $(10 \mathrm{ng} / \mathrm{mL})$, then the treatment skin tissue of sheep were sampled about $1 \mathrm{~cm}$ X $2 \mathrm{~cm}$ respectively for $0,3,6,9,12$ and 50 days. The obtained samples were immediately frozen in liquid nitrogen and stored at $-80^{\circ} \mathrm{C}$ until isolation of RNA.

\subsection{RT-PCR assay the abundance of GHR, IGF-1, IGF-1R, KAP3.2 and KAP6-1 mRNA}

Total RNA Isolation: Total RNA was extracted from the homogenized skin tissue according to the TRIzol instructions and quantified by UV absorbance. Obtaining the ratio of absorbance values at 260 and $280 \mathrm{~nm}$ assessed the quantity of the RNA, and its integrity confirmed by visualizing on $2.0 \%$ agarose gels with ethidium bromide staining. If the proportion of the net intensity of $28 \mathrm{~S}$ and $18 \mathrm{~S}$ near or above 2.0 , and no trailing smear and other bands, we can assure the quality reliability of RNA integrity.

Reverse transcription: Each cDNA obtained from total RNA was reverse transcribed by random primers. Reverse transcription reaction contained $2 \mathrm{ug}$ total RNA, 5uM random primers, $0.5 \mathrm{mM}$ dNTP, 20U RNase inhibitor,200U inverse transcriptase(M-MLV-RT), $5 \mu \mathrm{L} 10 \times \mathrm{RTBuffer}\left(250 \mathrm{~mol} \cdot \mathrm{L}-1 \quad\right.$ Tris $\mathrm{HCl}(\mathrm{pH} 8.3), 50 \mathrm{~mol} \cdot \mathrm{L}^{-1} \quad \mathrm{MgCl}_{2}, 250 \mathrm{~mol} \cdot \mathrm{L}^{-1}$ $\mathrm{KCl}, 50 \mathrm{~mol} \cdot \mathrm{L}^{-1} \mathrm{DTT}, 2.5 \mathrm{~mol} \cdot \mathrm{L}^{-1}$ Spermidine), in a total volume of $20 \mu \mathrm{L}$. The mixture of total RNA, dNTP and random primers was incubated at $75^{\circ} \mathrm{C}$ for 5 minutes, then kept cool snap in ice, put in other reagents. Conditions used were $37^{\circ} \mathrm{C}$ for 60 minutes, and $95^{\circ} \mathrm{C}$ for 5 minutes.

PCR amplification reactions: The primers sequence of GHR, IGF-1, IGF-1R, KAP3.2, KAP6-1 and beta-actin were designed according to cDNA sequence of sheep GHR (M82912), IGF-1 (M30653), IGF-1R (X54980), KAP3.2 (AY483216), KAP6-1 (M95719) and $\beta$-actin (U39357) in GenBank. The primers sequence and PCR amplification conditions were shown in Table 1 and Table 2. Each reverse transcription product contained two repeats, as a control, using $\mathrm{ddH}_{2} \mathrm{O}$ and total RNA sample replace $\mathrm{RT}$ (reverse transcription) product that check out if there having extrinsic DNA and genome DNA contaminates. To correct the efficiency difference of reverse transcription and PCR between different batches, the best PCR reaction conditions were established with the mixture that the same volume mixed all total RNA.

PCR reaction conditions included $2 \mathrm{ug}$ RT product, $2 \mathrm{U}$ Taq DNA polymerase, $5 \mathrm{uL} 10 \times \mathrm{buffer}\left(50 \mathrm{~mol} \cdot \mathrm{L}^{-1}\right.$ Tris-HCl(pH9.0), $100 \mathrm{~mol} \cdot \mathrm{L}^{-1} \mathrm{NaCl}, 1.0 \mathrm{~mol} \cdot \mathrm{L}^{-1} \mathrm{DTT}, 0.1 \mathrm{~mol} \cdot \mathrm{L}^{-1}$ EDTA,50\%glycerol, $10 \%$ TritonX100), $0.2 \mathrm{mmol} \cdot \mathrm{L}^{-1} \quad \mathrm{dNTP}$, 1.0 2.0mol $\cdot \mathrm{L}^{-1} \mathrm{MgCl}_{2}, 0.5 \mu \mathrm{mol} \cdot \mathrm{L}^{-1}$ target gene primers and proper $\beta$-actin primers.

Electrophoresis and intensity analysis: Reslting PCR products(10-20ul) were analyzed by electrophoresis on $2.0 \%$ agarose gels, with DNA visualized by ethidium bromide staining. LabWork3.0 Analysis System could be used to analyze the electrophoresis photo and bands intensity. The relative abundance of target gene mRNA in samples would be assayed according to the ratio of bands intensity between target gene and beta-actin.

\subsection{Statistical analysis of experiments data}

Experiments data obtained from skin specimen were analyzed using ANOVA of STATISTICA Software, and its statistical significance was analyzed by LSD test.

\section{Results}

The relative abundance of GHR mRNA did not significant changes in skin tissues injected IGF-1, compared with control, but there was a gradual falling tendency in general (Fig1). The findings indicated that IGF-1 could down regulate the expression of GHR gene in sheepskin.

The Fig2 and Fig3 shown that the expression of IGF-1 and IGF-1R beyond $32.29 \%$ and $36.29 \%$ respectively, but did not reached statistical significance. The results suggested that subcutaneous injection of IGF-1 has no evidently effect on levels of IGF-1 and IGF-1R mRNA.

The Fig4 and Fig5 displayed that levels of KAP3.2 and KAP6-1 mRNA have no clear fluctuation between 0 and 3 days, then increased gradually between 3 and 9 days, and reached the peak marked difference in 9 day, subsequently decreased significantly and restored the levels before injection IGF-1. The findings claim that the level of KAP3.2 and KAP6-1 mRNA expression was improved remarkably by injecting IGF-1 in subcutaneous tissue.

\section{Discussion}

Extensive findings indicate that there was expression of GHR, IGF-1, IGF-1R and IGFBPs in sheepskin and hair follicle. Growth hormone can improve the expression of IGF-1 gene, while IGF-1 may selectively inhibit the transcription of growth hormone and affect on the expression of growth hormone receptor. IGF-1 may cause the cell proliferation and the expression of IGF-1R, which decreased evidently in high differentiation epidermal cell or tumor cell. Hocking et al finds that the endogenous IGF-1 reduced significantly within 7 day of IGF-1 infusion, and then increased remarkably. 
Our results indicate that IGF-1 has fall-down effect on expression of growth hormone receptor and no significant effect on expression of IGF-1 and IGF-1R.

IGF-1 could be able to improve the growth of hair follicle through regulate the androgen in vivo and in vitro, however, hair follicles maintained in the absence of IGF-1 showed premature entry into a catagen-like state. Growth hormone had no effect on hair follicle growth or morphology in the absence of IGF-1. The changes of IGF-1R expression vary from site to site during hair cycles. These results suggest that IGF-1 and its receptor play an important role in regulating hair follicle growth. In contrast, the results in vivo fall out of to in vitro. Cottam et al (1992) injected IGF-1 to lamb and then the concentration of IGF-1 in blood flow increased, but no effects were found in the wool growth after 8 weekends. The results injected IGF-1 to local sheepskin demonstrate that IGF-1 caused protein synthesis increase on short term, while the synthesis of protein decreased on long term and wool growth still remained the same. Our results suggest that IGF-1 caused keratin-associated protein 3.2 (KAP3.2) and keratin associated protein 6-1 (KAP6-1) expression increase, possibly IGF-1 caused keratin synthesis through other pathway beyond the insulin-like growth factor axis.

\section{References}

Shen, S., Alt, A., Wertheimer, E., et al. 2001. PKCdelta activation: a divergence point in the signaling of insulin and IGF-1-induced proliferation of skin keratinocytes. Diabetes, 50(2),255-64.

Rudman, SM., Philpott, MP., Thomas, GA., et al. 1997. The role of IGF-1 in human skin and its appendages: morphogen as well as mitogen? J Invest Dermatol, 109(6), 770-7.

Kamiya, T., Shirai, A., Kawashima, S., et al. 1998. Hair follicle elongation in organ culture of skin from newborn and adult mice. $J$ Dermatol Sci, 17, 54-60.

Dicks, P., Morgan, CJ., Morgan, PJ., et al. 1996. The localisation and characterisation of insulin-like growth factor-I receptors and the investigation of melatonin receptors on the hair follicles of seasonal and non-seasonal fibre-producing goats. J Endocrinol, 151(1),55-63.

Lewis, AJ., Wester, TJ., Burrin, DG., et al. 2000. Exogenous growth hormone induces somatotrophic gene expression in neonatal liver and skeletal muscle. Am J Physiol Regul Integr Comp Physiol, 278(4), R838-44.

Dupont, J., Holzenberger, M. 2003. Biology of insulin-like growth factors in development. Birth Defects Res Part C Embryo Today; 69(4), 257-71.

Fruchtman, S., Gift, B., Howes, B, et al. 2001. Insulin-like growth factor-I augments prolactin and inhibits growth hormone release through distinct as well as overlapping cellular signaling pathways. Comp Biochem Physiol B Biochem Mol Biol, 129(2-3),237-42.

Kajimura S, Uchida K, Yada T, et al. 2002. Effects of insulin-like growth factors (IGF-I and -II) on growth hormone and prolactin release and gene expression in euryhaline tilapia, Oreochromis mossambicus. Gen Comp Endocrinol, 127(3), 223-31.

Melmed S, Yamashita S, Yamasaki H, et al. 1996. IGF-I receptor signalling: lessons from the somatotroph. Recent Prog Horm Res, 51,189-215; discussion 215-6.

Fruchtman S, McVey DC. \& Borski RJ. 2002. Characterization of pituitary IGF-I receptors: modulation of prolactin and growth hormone. Am J Physiol Regul Integr Comp Physiol, 283(2), R468-76.

Hodak E, Gottlieb AB, Anzilotti M, et al . 1996 . The insulin-like growth factor 1 receptor is expressed by epithelial cells with proliferative potential in human epidermis and skin appendages: correlation of increased expression with epidermal hyperplasia. J Invest Dermatol, 106(3), 564-70.

Romano, G. 2003. The complex biology of the receptor for the insulin-like growth factor-1. Drug News Perspect, 16(8), $525-31$.

Hocking Edwards, JE., Khalaf, SK., Sinclaire, BR., et al. 1995. Metabolic response of sheep skin to a chronic infusion of a variant of insulin-like growth factor I. Biochem J, 308 (Pt 2), 411-8.

Little, JC., Redwood, KR., Stones, AJ., Gibson, WT. \& Granger, SP. 1994. The insulin-like growth factors are important in controlling the hair growth cycle. J Invest Dermatol, 102, 533.

Lobley, GE., Lee, J., Hocking Edwards, J., et al. 1997, A comparison of changes in whole body and skin amino acid metabolism of sheep in response to $24 \mathrm{~h}$ continuous infusion of variants of insulin-like growth factor 1. Canda J Anim Sci, 77, 695-706. 
Table 1. Parameters of oligo-nucleotide primer pairs for the oGHR, oIGF-I, oIGF-IR,oKAP3.2,oKAP6-1 and oß-actin

\begin{tabular}{|c|c|c|c|}
\hline target gene & sequence origin & primer sequence & PCR product \\
\hline \multirow{3}{*}{ oGHR } & GenBank & F·5'-AGGTTGCTCAGCCACAAA-3' & $281 \mathrm{bp}$ \\
\hline & M82912 & R:5'-TGGGGAAAGGACCACATT-3' & $(1412-169$ \\
\hline & & & 2) \\
\hline \multirow{2}{*}{ oIGF-1 } & GenBank & F:5'-AGTTGGTAGATTGCTGTTGAT-3' & $277 \mathrm{bp}$ \\
\hline & M30653 & R:5'-GAGAAGGGAGCGGGATAG-3' & $(680-956)$ \\
\hline \multirow{2}{*}{ oIGF-1R } & GenBank & F:5'-GCGGTTCTGTTGATAGTGG-3' & $287 \mathrm{bp}$ \\
\hline & X54980 & R:5'-GCCTCGTTCACCGTCTTA-3' & $(646-932)$ \\
\hline \multirow{2}{*}{ oKAP3.2 } & GenBank & F:5'-TCATCAACCCAACAAAACC-3' & $322 b p$ \\
\hline & AY483216 & R:5'-GGGGCTCGCAGACATT-3' & $(20-341)$ \\
\hline \multirow{2}{*}{ oKAP6-1 } & GenRank & 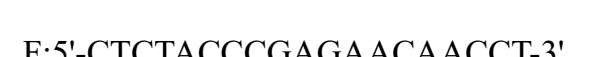 & $296 b p$ \\
\hline & M95719 & R:5'-TCGTGGCATCCTCAATAGT-3' & $(1010-130$ \\
\hline \multirow{3}{*}{$o \beta$-actin } & & & $467 \mathrm{bn}$ \\
\hline & GenBank & F:5'-GCAGGTCATCACCATCGG-3' & $(821-1287$ \\
\hline & & GCCAATCTCATCTCGTTT & \\
\hline
\end{tabular}

Table 2. RT-PCR condition for skin GHR, IGF-1, IGF-1R, KAP3.2 and KAP6-1 mRNA in sheep

\begin{tabular}{|c|c|c|c|c|c|}
\hline & GHR & IGF-1 & IGF-1R & KAP3.2 & KAP6-1 \\
\hline $\begin{array}{c}\text { PCR } \\
\text { conditions }\end{array}$ & $\begin{array}{c}0.8 \mathrm{~mol} / \mathrm{LMgCl}_{2}, \\
94^{\circ} \mathrm{C} 30 \mathrm{~s}, 56^{\circ} \mathrm{C} 45 \mathrm{~s}, \\
72^{\circ} \mathrm{C} 30 \mathrm{~s} \\
30 \text { cycles }\end{array}$ & $\begin{array}{c}0.8 \mathrm{~mol} / \mathrm{LMgCl}_{2}, \\
94^{\circ} \mathrm{C} 30 \mathrm{~s}, 56^{\circ} \mathrm{C} 45 \mathrm{~s}, \\
72^{\circ} \mathrm{C} 60 \mathrm{~s}, \\
31 \mathrm{cycles}\end{array}$ & $\begin{array}{c}0.8 \mathrm{~mol} / \mathrm{LMgCl}_{2}, \\
94^{\circ} \mathrm{C} 30 \mathrm{~s}, 56^{\circ} \mathrm{C} 45 \mathrm{~s}, \\
72^{\circ} \mathrm{C} 30 \mathrm{~s}, \\
31 \mathrm{cycles}\end{array}$ & $\begin{array}{c}0.8 \mathrm{~mol} / \mathrm{LMgCl}_{2}, \\
94^{\circ} \mathrm{C} 30 \mathrm{~s}, 56^{\circ} \mathrm{C} 45 \mathrm{~s}, \\
72^{\circ} \mathrm{C} 30 \mathrm{~s}, \\
30 \text { cycles }\end{array}$ & $\begin{array}{c}0.8 \mathrm{~mol} / \mathrm{LMgCl}_{2}, \\
94^{\circ} \mathrm{C} 30 \mathrm{~s}, 61^{\circ} \mathrm{C} 45 \mathrm{~s}, \\
72^{\circ} \mathrm{C} 30 \mathrm{~s}, \\
30 \text { cycles }\end{array}$ \\
\hline
\end{tabular}
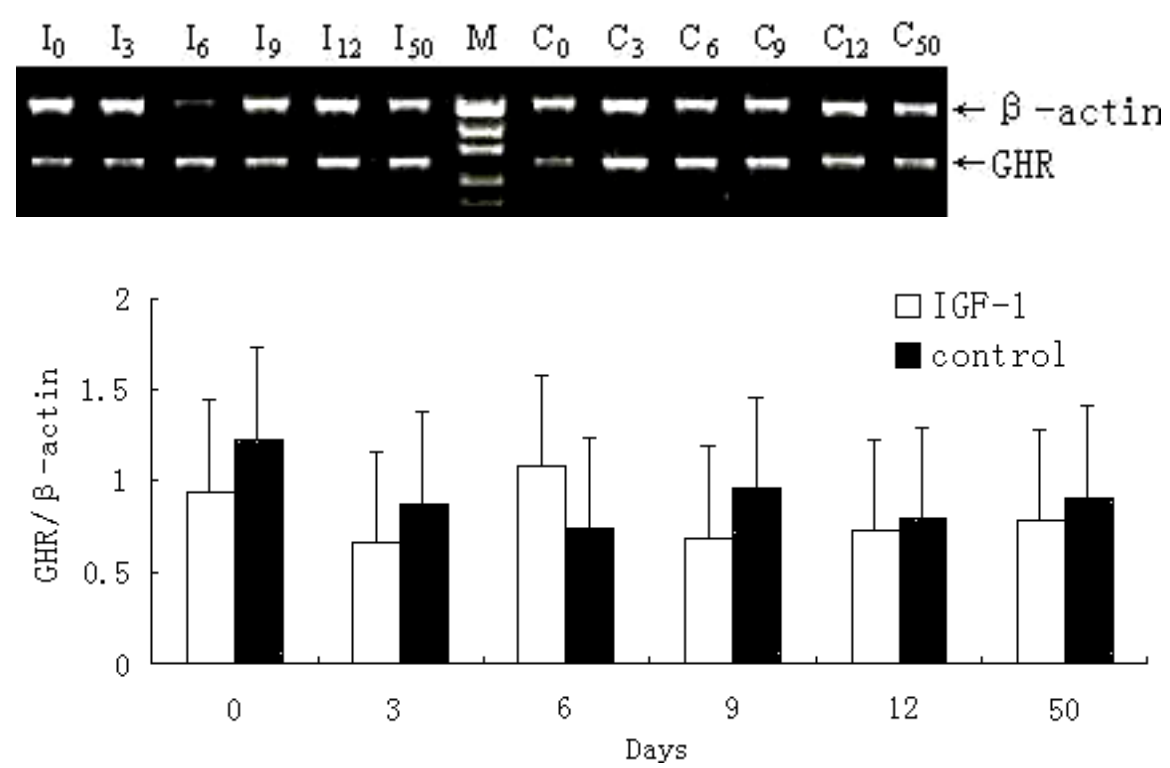

Figure 1. Effect of IGF-1 on relative abundance of skin GHR mRNA

Up: Representative agarose gel electrophoresis photo of RT-PCR result. $\mathrm{I}_{0} \sim \mathrm{I}_{50}$ represent injection IGF-1 day $0 \sim 50$ respectively, $\mathrm{C}_{0} \sim \mathrm{C}_{50}$ represent control skin day 0 50 respectively; M: Marker (PUC19). Down: result analysis of effect of IGF-1 on relative abundance of GHR mRNA in skin, $\mathrm{n}=6$. * $\mathrm{P}<0.05$; ** $\mathrm{P}<0.01$. 

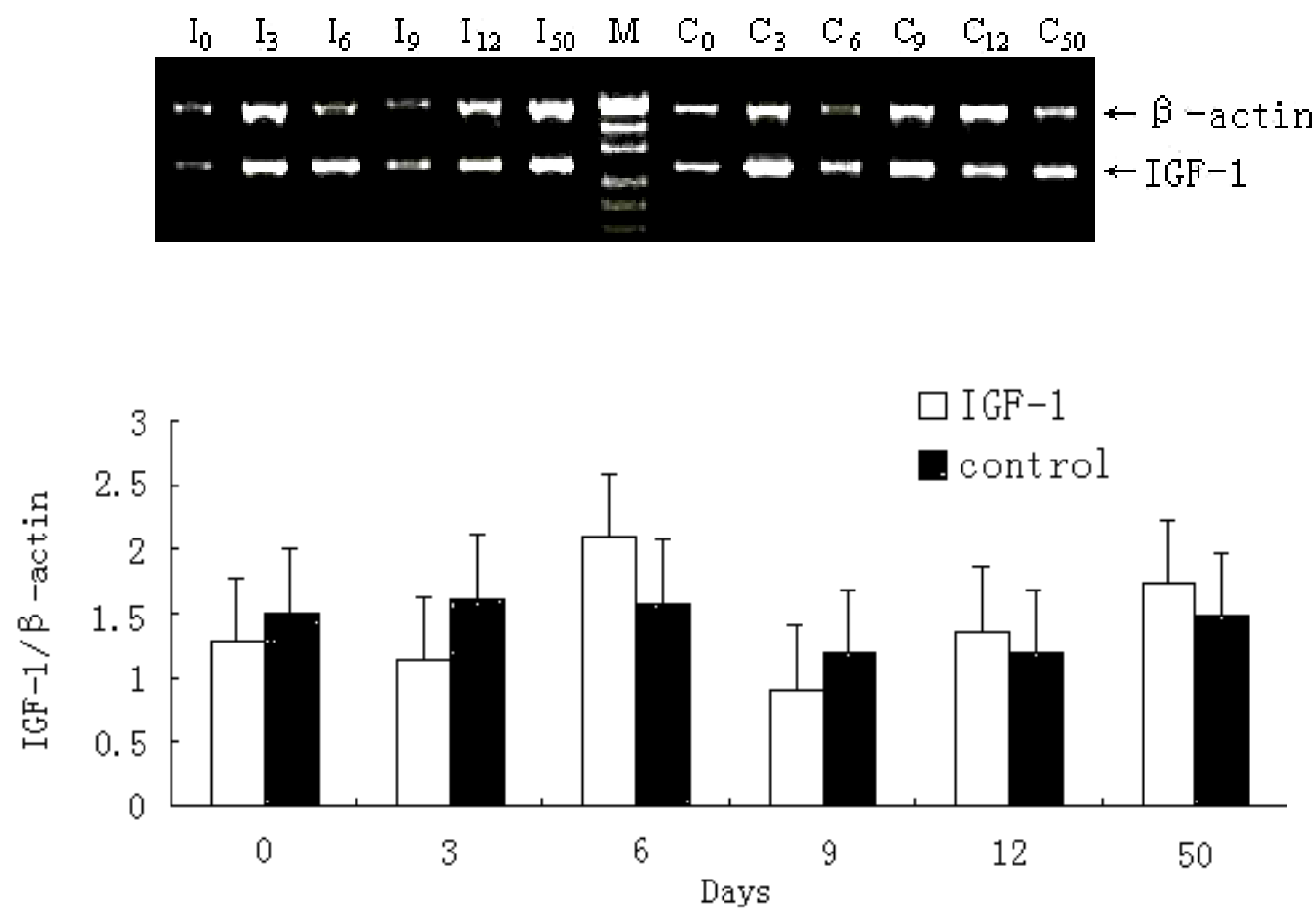

Figure 2. Effect of IGF-1 on relative abundance of skin IGF-1 mRNA

Up: Representative agarose gel electrophoresis photo of RT-PCR result. I0 I50 represent injection IGF-1 day 0 50 respectively, C0 C50 represent control skin day 0 50 respectively; M: Marker (PUC19). Down: result analysis of effect of IGF-1 on relative abundance of IGF-1 mRNA in skin, $\mathrm{n}=6 . * \mathrm{P}<0.05 ; * * \mathrm{P}<0.01$.
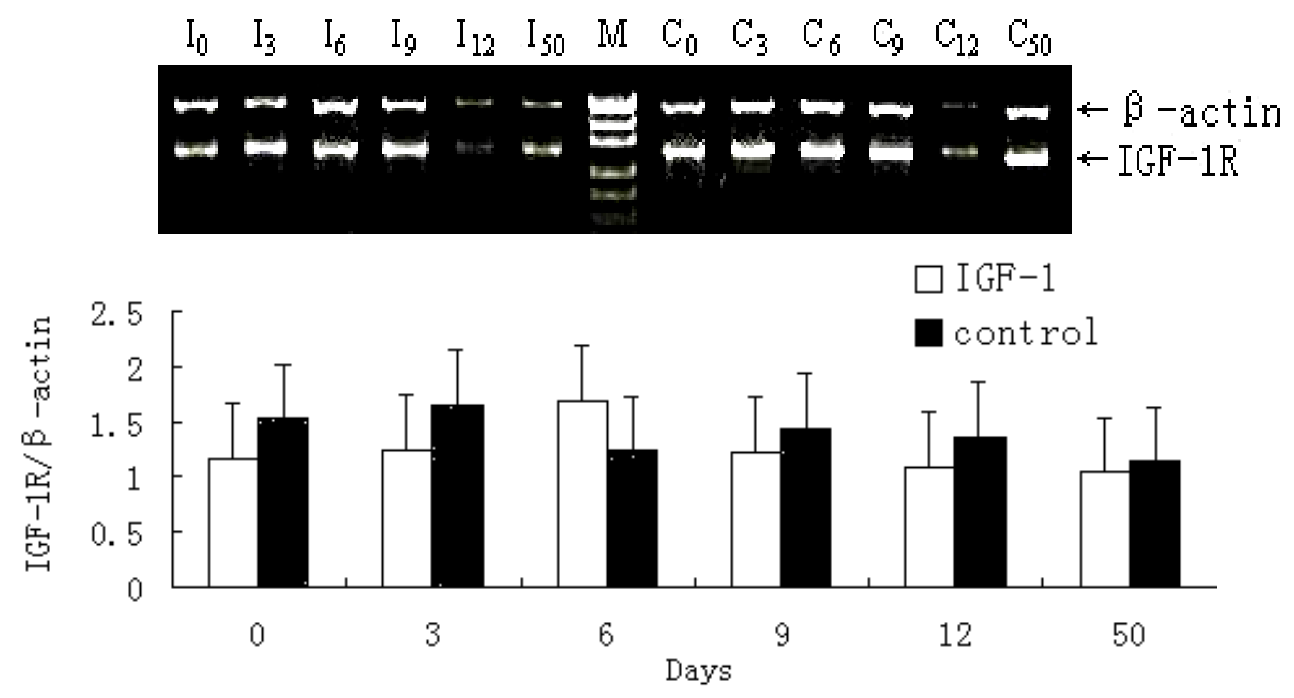

Figure 3. Effect of IGF-1 on relative abundance of skin IGF-1R mRNA

Up: Representative agarose gel electrophoresis photo of RT-PCR result. I0 I50 represent injection IGF-1 day 0 50 respectively, C0 C50 represent control skin day 0 50 respectively; M: Marker (PUC19). Down: result analysis of effect of IGF-1 on relative abundance of IGF-1R mRNA in skin, $\mathrm{n}=6$. ${ }^{*} \mathrm{P}<0.05$; ${ }^{* *} \mathrm{P}<0.01$. 

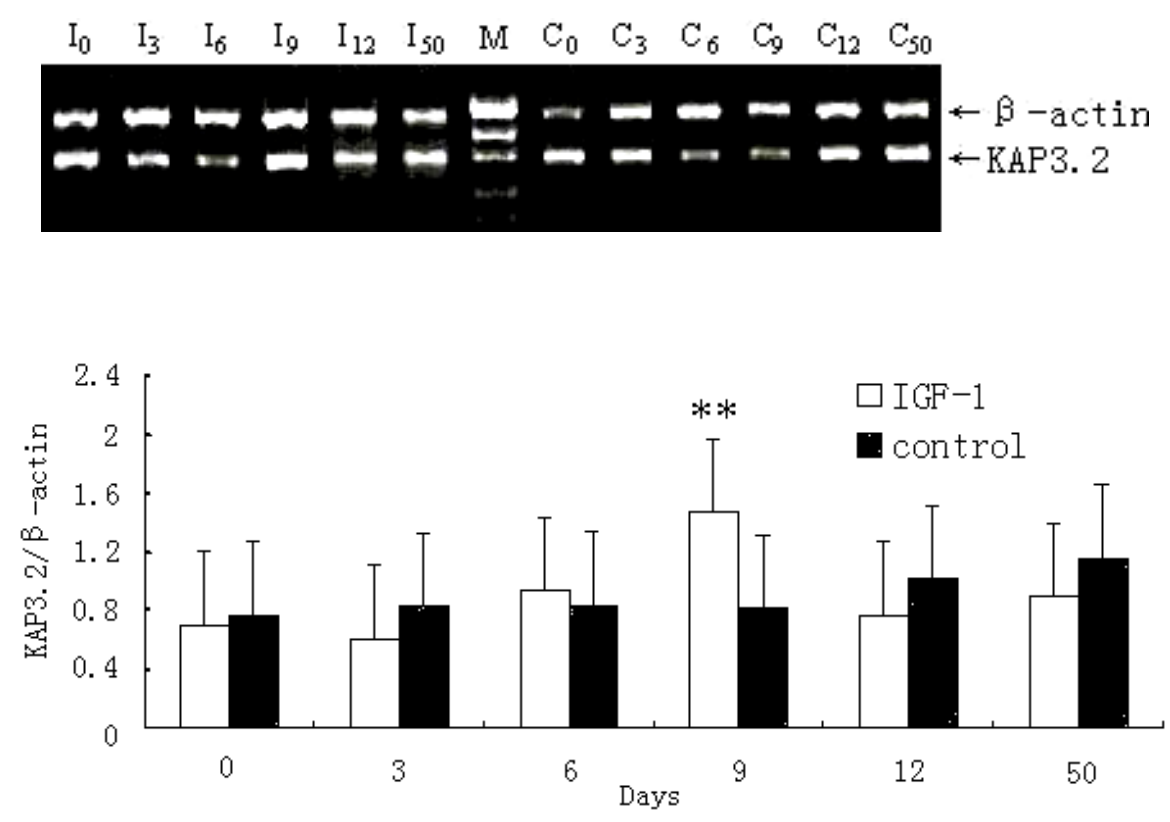

Figure 4. Effect of IGF-1 on relative abundance of skin KAP3.2 mRNA

Up: Representative agarose gel electrophoresis photo of RT-PCR result. $\mathrm{I}_{0} \sim \mathrm{I}_{50}$ represent injection IGF-1 day $0 \sim 50$ respectively, $\mathrm{C}_{0} \sim \mathrm{C}_{50}$ represent control skin day 0 50 respectively; M: Marker (PUC19). Down: result analysis of effect of IGF-1 on relative abundance of KAP3.2 mRNA in skin, $\mathrm{n}=6$. $* \mathrm{P}<0.05$; * $\mathrm{P}<0.01$.
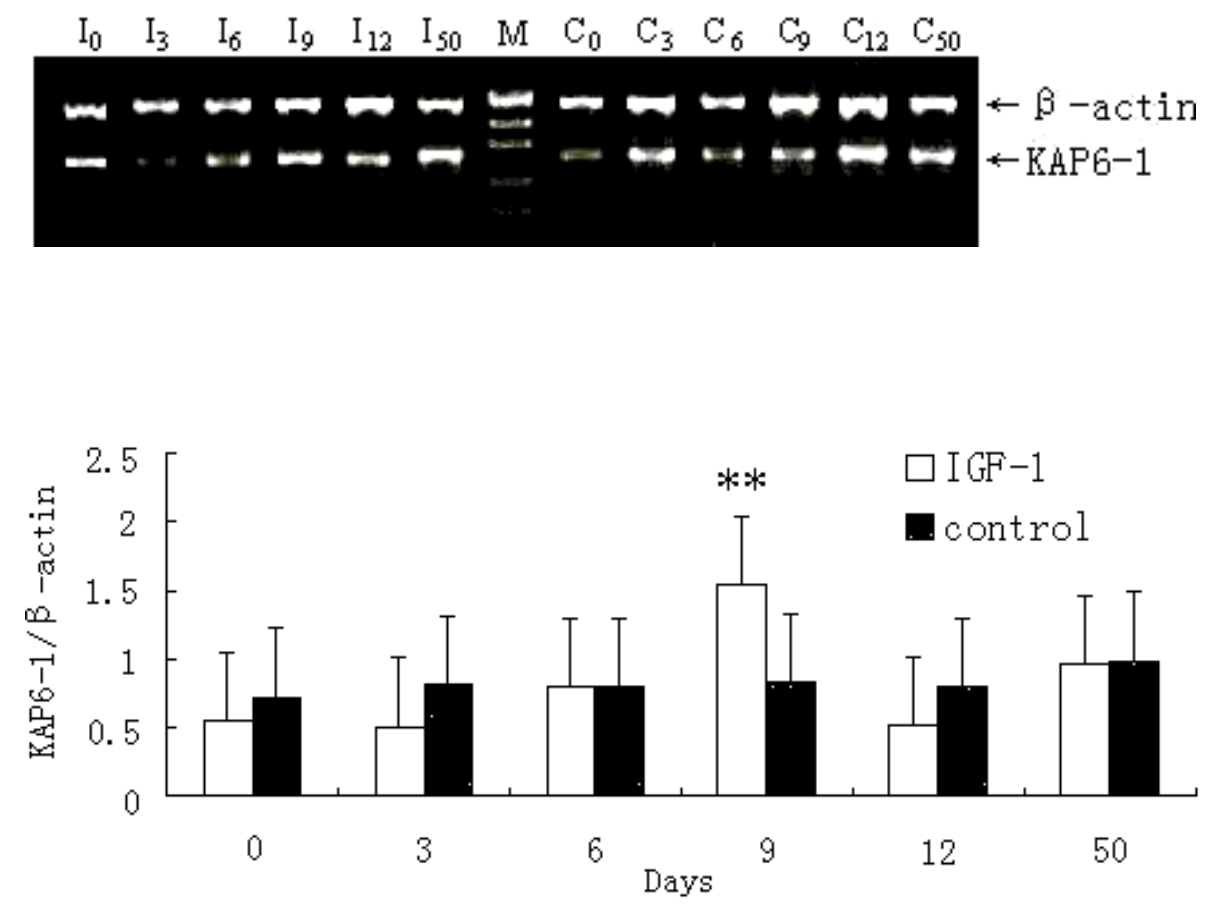

Figure 5. Effect of IGF-1 on relative abundance of skin KAP6-1 mRNA

Up: Representative agarose gel electrophoresis photo of RT-PCR result. $\mathrm{I}_{0} \sim \mathrm{I}_{50}$ represent injection IGF-1 day $0 \sim 50$ respectively, $\mathrm{C}_{0} \sim \mathrm{C}_{50}$ represent control skin day 0 50 respectively; M: Marker (PUC19). Down: result analysis of effect of IGF-1 on relative abundance of KAP6-1 mRNA in skin, $\mathrm{n}=6$. * $\mathrm{P}<0.05 ; * * \mathrm{P}<0.01$. 